\title{
Combined low-volume polyethylene glycol solution plus stimulant laxatives versus standard-volume polyethylene glycol solution: A prospective, randomized study of colon cleansing before colonoscopy
}

\author{
Lawrence C Hookey MD, William T Depew MD, Stephen J Vanner MD
}

\begin{abstract}
LC Hookey, WT Depew, SJ Vanner. Combined low-volume polyethylene glycol solution plus stimulant laxatives versus standard-volume polyethylene glycol solution: A prospective, randomized study of colon cleansing before colonoscopy. Can J Gastroenterol 2006;20(2):101-105.
\end{abstract}

INTRODUCTION: The effectiveness of polyethylene glycol solutions (PEG) for colon cleansing is often limited by the inability of patients to drink adequate portions of the $4 \mathrm{~L}$ solution. The aim of the present study was to determine whether a reduced volume of PEG combined with stimulant laxatives would be better tolerated and as or more effective than the standard dose.

METHODS: Patients undergoing outpatient colonoscopy were randomly assigned to receive either low-volume PEG plus sennosides (120 mg oral sennosides syrup followed by 2 L PEG) or the standard volume preparation (4 L PEG). The subjects rated the tolerability of the preparations and their symptoms. Colonoscopists were blind to the colonic cleansing preparation and graded the cleansing efficacy using a validated tool (the Ottawa scale).

RESULTS: The low-volume PEG plus sennosides preparation was significantly better tolerated than the standard large volume PEG $(\mathrm{P}<0.001)$ but was less efficacious $(\mathrm{P}=0.03)$. Thirty-eight per cent of patients in the large volume PEG group were unable to finish the preparation, compared with only $6 \%$ in the reduced volume group. There were no adverse events reported.

CONCLUSIONS: Although the low-volume PEG plus sennosides preparation was better tolerated, it was not as effective as standard large-volume PEG. However, in view of the significant difference in tolerance, further research investigating possible improvements in the reduced-volume regimen seems warranted.

Key Words: Colonoscopy; Preparation; Tolerance; Volume
Étude prospective, avec hasardisation, sur le net- toyage du côlon avant la coloscopie : comparaison entre une petite quantité de solution de polyéthylèneglycol et des laxatifs stimulants, et une quantité normale de solution de polyéthylèneglycol

\begin{abstract}
INTRODUCTION : L'efficacité de la solution de polyéthylèneglycol (PEG) pour le nettoyage du côlon est souvent limitée par l'incapacité des patients à en boire une quantité suffisante (solution de 4 litres [1]). La présente étude avait pour but de déterminer si une quantité réduite de solution de PEG, associée à des stimulants laxatifs se tolérait mieux et pouvait se montrer aussi efficace, sinon plus, que la quantité normale de solution. MÉTHODE : Les patients, qui devaient subir une coloscopie en externe, ont reçu au hasard soit une petite quantité de solution de PEG et du sennoside (120 mg de sennoside en sirop, par voie orale, et 21 de solution de PEG), soit la quantité habituelle de solution de PEG (4 1). Les sujets ont ensuite noté la tolérabilité de la préparation et leurs symptômes. Les médecins, de leur côté, tenus dans l'ignorance du type de préparation utilisé pour le nettoyage du côlon, ont coté l'efficacité du nettoyage à l'aide d'un outil validé (l'échelle d'Ottawa).

RÉSULTATS : La petite quantité de solution de PEG, complétée par le sirop de sennoside a été sensiblement mieux tolérée que la grande quantité normale de solution de PEG $(\mathrm{P}<0,001)$, mais elle s'est montrée moins efficace $(\mathrm{P}=0,03)$ que l'autre. Trente-huit pour cent des patients devant boire la grande quantité de solution de PEG ont été incapables de finir la bouteille contre $6 \%$ seulement dans l'autre groupe. Aucun effet indésirable n'a été signalé.

CONCLUSIONS : Même si la préparation composée d'une petite quantité de solution de PEG et de sennoside a été mieux tolérée, elle ne s'est pas montrée aussi efficace que la préparation habituelle, composée d'une grande quantité de solution de PEG. Toutefois, compte tenu de l'importance de l'écart en ce qui concerne la tolérabilité, il serait justifié de poursuivre les recherches afin de trouver des améliorations possibles à la préparation allégée.
\end{abstract}

$T_{\text {hed }}^{\text {hed }}$ he demand for colonoscopy continues to increase largely due to the emerging recommendations for colon screening for colorectal cancer. Moreover, studies (1) suggest that the bowel preparation process is the single greatest deterrent to subsequent screening. In the past decade, colonic cleansing has been accomplished using large-volume colonic lavage with polyethylene glycol (PEG) $(2,3)$, osmotic agents such as oral sodium phosphate $(4-6)$, stimulant laxatives $(7,8)$ or various combinations of these (9-12). Difficulties with these preparations include varying efficacy, poor patient tolerance and safety concerns (3,13-16). With PEG lavage, patients experience problems completing the preparation due to the large-volume
(4 L) required to be ingested over a relatively short period of time ( $1 \mathrm{~h}$ to $2 \mathrm{~h}$ ) (3). While the ideal colon cleansing preparation is safe, well tolerated, effective and without contraindications, the search for such a combination continues.

Combining a stimulant laxative with PEG has the potential to reduce the volume necessary for an effective colonic cleansing while possibly improving tolerance. Iida et al (17) combined sennosides with $2 \mathrm{~L}$ of PEG and observed favourable results. However, the validity of these findings is unclear due to the lack of a control group and, thereby, random assignment and poor questionnaire response rates by both patients and endoscopists ( $60 \%$ and $54 \%$, respectively). Given these findings 
TABLE 1

Baseline characteristics

\begin{tabular}{lcc}
\hline & $\begin{array}{c}\text { Low-volume PEG plus } \\
\text { plus sennosides }(\mathbf{n = 7 9 )}\end{array}$ & PEG (n=81) \\
\hline Age & $57 \pm 15$ & $54 \pm 12.7$ \\
Sex ratio male:female & $35: 44$ & $38: 43$ \\
Reason for colonoscopy & & \\
Colorectal cancer screening & 50 & 64 \\
Anemia/rectal bleeding & 10 & 3 \\
Inflammatory bowel disease & 4 & 4 \\
Change in bowel habit & 15 & 10 \\
\hline
\end{tabular}

PEG Polyethylene glycol solution

and our interest in improving the tolerability and efficacy of PEG, the aim of the current study was to conduct a prospective, randomized, endoscopist-blind, clinical trial to determine the efficacy and tolerability of low-volume PEG solution (2 L) combined with stimulant laxatives. Options for timing of the dosing of sennosides, relative to the PEG dose, include $6 \mathrm{~h}$ before or immediately before. We chose the latter to assist the transit of PEG and increase the convenience of the preparation.

\section{METHODS}

Patients scheduled for outpatient colonoscopy at the Hotel Dieu Hospital, Kingston, Ontario were considered for enrollment. Exclusion criteria included pregnancy, ileus, previous colonic resection or recent (less than six months) myocardial infarction or unstable angina. Informed consent was obtained from all patients and the study was approved by the Queen's University Health Sciences and Affiliated Teaching Hospitals Research Ethics Board.

Random assignment was performed using a computer-generated random number table. An opaque envelope was opened by the study nurse at the time of enrollment to reveal group assignment. She then explained the instructions for the appropriate preparation.

All patients were instructed to follow a clear fluid diet the day before colonoscopy. Patients in the control group were instructed to ingest $4 \mathrm{~L}$ of PEG over $1 \mathrm{~h}$ to $2 \mathrm{~h}$, starting at 18:00 the evening before the procedure. Patients assigned to the low-volume PEG plus sennosides group were instructed to ingest one $70 \mathrm{~mL}$ bottle of sennosides syrup (120 mg Senekot, X Prep solution, Purdue Pharma Canada) at 18:00 the night before the procedure. This was followed by $2 \mathrm{~L}$ of PEG, ingested over $1 \mathrm{~h}$ to $2 \mathrm{~h}$.

All patients had blood drawn at screening for electrolytes, renal function and complete blood count. Orthostatic hemodynamic measurements were made before and after ingestion (ie, the morning of colonoscopy) of the preparations.

After the preparation, but before colonoscopy, patients completed a nurse-administered questionnaire regarding preparation tolerance, which has been used and described in previous studies $(6,9)$. This inquired about overall tolerance, using a five-point Likert scale, specific symptoms (nausea, vomiting, abdominal or chest pain, dizziness and bloating) with yes or no response options, and percentage of preparation completed.

Colonoscopy was performed in standard fashion by an endoscopist blind to the study group assignment. At the end of the colonoscopy, the endoscopist graded colon cleanliness using the Ottawa scale, a simple colon cleansing scoring system demonstrated
TABLE 2

Baseline biochemistry

\begin{tabular}{lcc}
\hline & PEG & $\begin{array}{c}\text { Low-volume PEG } \\
\text { plus sennosides }\end{array}$ \\
\hline Hemoglobin, $\mathrm{g} / \mathrm{L}$ & $143.5 \pm 13.9$ & $141.6 \pm 16.3$ \\
Hematocrit, L/L & $0.473 \pm 0.440$ & $0.419 \pm 0.039$ \\
Sodium, $\mathrm{mmol} / \mathrm{L}$ & $139.9 \pm 2.6$ & $139.8 \pm 2.2$ \\
Chloride, $\mathrm{mmol} / \mathrm{L}$ & $104 \pm 2.7$ & $104 \pm 2.6$ \\
Potassium, $\mathrm{mmol} / \mathrm{L}$ & $4.34 \pm 0.31$ & $4.69 \pm 0.36$ \\
Blood urea nitrogen, $\mathrm{mmol} / \mathrm{L}$ & $6.3 \pm 4.8$ & $5.5 \pm 1.5$ \\
Creatinine, $\mu \mathrm{mol} / \mathrm{L}$ & $74.1 \pm 21$ & $74 \pm 16$
\end{tabular}

$P=$ Not significant for differences between groups. PEG Polyethylene glycol solution

to be reliable and valid (18). This scale assesses the colon cleanliness in the right-, mid- and rectosigmoid colon, scoring between 0 and 4 for each section, with 0 being the cleanest and an additional score between 0 and 2 for total fluid present. The sum of these scores is then taken for a total score out of 14 , with 0 being the optimal score and 14 the worst.

\section{Statistics}

A power calculation was performed based on the assumptions that approximately $70 \%$ of patients receiving PEG solution have a good or excellent colon cleansing and approximately 50\% feel the preparation is easy or tolerable. These estimates are based on previous studies $(3,5,6,19-26)$ of the solution. Using this collapsed format of the ordinal scales for tolerance and efficacy in a $\chi^{2}$ test, to detect a $20 \%$ difference in effectiveness of colon cleansing and patient tolerance, with an alpha of 0.05 and $80 \%$ confidence level, 80 patients would be required in each group.

Noncontinuous ordinal data were analyzed using the $\chi^{2}$ test with linear by linear association. Noncontinuous, nominal data were analyzed with proportions using the Pearson $\chi^{2}$ method. Continuous data were analyzed comparing means using Student's $t$ test. Unfortunately, colonoscopy was incomplete in 10 patients (PEG, n=4; low-volume PEG plus sennosides, $n=6$ ) for reasons other than preparation quality (unable to continue examination due to significant angulations of colon/obstructing lesion, $n=7$; examination stopped due to patient discomfort, $n=3$ ). Analysis was performed excluding these patients, and by assigning the worst possible cleanliness score to each of these patients. As the results were similar, with no change in conclusions or significance, colon cleanliness data are presented excluding those patients. However, their tolerance data are included in the analysis. All data were analyzed using SPSS 11.5 (SPSS Inc, USA).

\section{RESULTS}

One hundred seventy-one patients were enrolled in the study, which included 11 additional patients that were enrolled to account for the procedures cancelled by the patient or physician before ingestion of preparation (11 cases). Colonoscopy was incomplete in 10 patients (PEG, n=4; low-volume PEG plus sennosides, $n=6$ ) for reasons other than preparation quality. Hence, colonoscopy cleanliness data were available for 77 patients in the PEG group and 73 patients in low-volume PEG plus sennosides group, while tolerance data were available for 81 patients in the PEG group and 79 in the low-volume PEG plus sennosides group. 


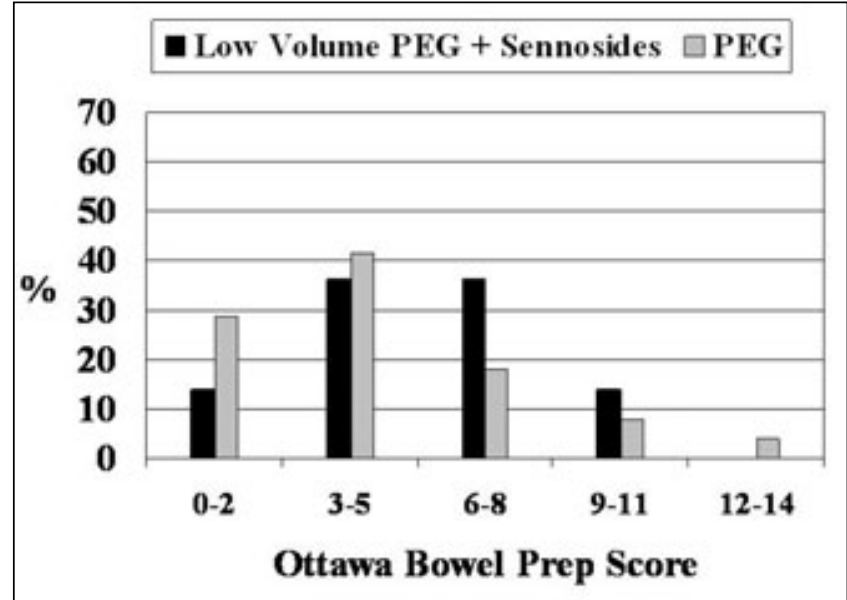

Figure 1) Quality of colon cleansing. Results are displayed according to the Ottawa scale of colon cleanliness, in which 0 is the best possible score and 14 is the worst. A significant difference was observed between the preparations $\left(P=0.03, \chi^{2}\right.$ with linear by linear association). PEG Polyethylene glycol

There were no significant differences between the groups with respect to age, sex distribution, reason for colonoscopy, baseline blood work or hemodynamics (Tables 1 and 2).

A significant difference between the two preparations in the quality of colon cleansing was seen in favour of PEG $(\mathrm{P}=0.03)$ (Figure 1). Forty-three per cent of patients in the PEG group scored between 0 and 3 on the Ottawa scale, corresponding to a good or excellent preparation, compared with $23 \%$ in the low-volume PEG plus sennosides group (Table 3 ).

However, low-volume PEG plus sennosides was better tolerated than PEG $(\mathrm{P}<0.001)$ (Figure 2$)$. Fifty-five per cent of patients in the study group rated the preparation as easy or tolerable, compared with 33\% in the PEG group. As well, 38\% of patients in the PEG group were unable to finish the preparation, compared with only $6 \%$ in the low-volume PEG plus sennosides group. However, there was no significant difference in preparation quality between those patients able and those unable to complete the full volume of PEG. No difference was observed with respect to tolerance nor quality of preparation when sex was considered.

There were no significant differences in symptom scores for nausea, vomiting, chest or abdominal pain, dizziness or bloating.

With respect to safety, there were no reported adverse events nor were there significant differences between the groups' postural hemodynamic measurements before and after preparation (Table 4).

\section{DISCUSSION}

While the indications for colonoscopy continue to expand, preprocedure colon cleansing continues to be a major obstacle for both the colonoscopist and patient. Although PEG can have reasonable efficacy, it is hampered by low patient tolerance due to its large volume. This problem is highlighted by the number of studies $(11,17,23,27-38)$ aimed to increase the efficacy of full-volume PEG or reduce the volume necessary and, thereby, increase patient acceptance. The results of the current study show that low-volume PEG combined with

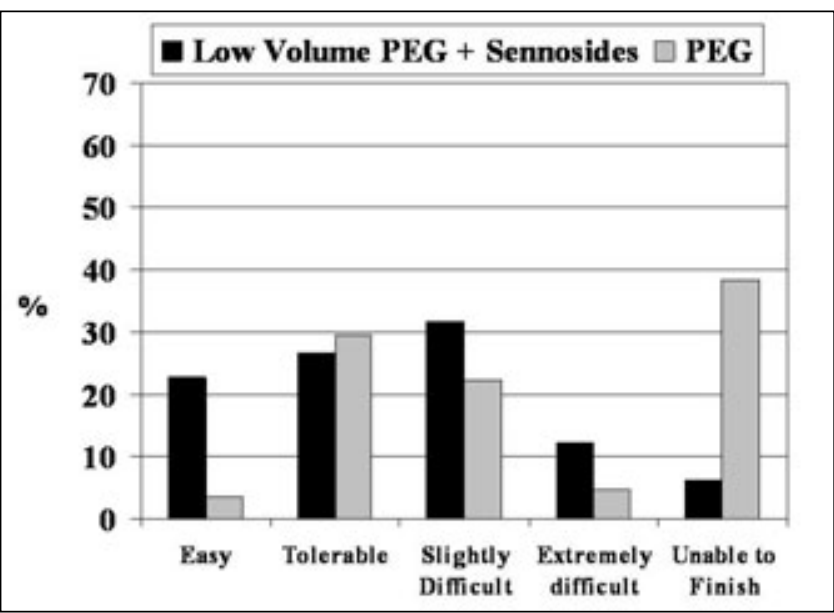

Figure 2) Tolerance of preparation. A significant difference was observed in favour of the low-volume polyethylene glycol (PEG) plus sennosides $\left(P<0.001, \chi^{2}\right.$ with linear by linear association $)$

TABLE 3

Colonoscopy cleansing results by the Ottawa scale

\begin{tabular}{lcc}
\hline Score* & $\begin{array}{c}\text { Low-volume PEG } \\
\text { plus sennosides }\end{array}$ & PEG \\
\hline 0 & 0 & 9 \\
1 & 5 & 8 \\
2 & 5 & 5 \\
3 & 7 & 11 \\
4 & 10 & 10 \\
5 & 9 & 11 \\
6 & 10 & 4 \\
7 & 10 & 8 \\
8 & 6 & 2 \\
9 & 8 & 3 \\
10 & 2 & 2 \\
11 & 0 & 1 \\
12 & 0 & 1 \\
13 & 0 & 1 \\
14 & 0 & 1 \\
\hline
\end{tabular}

${ }^{*} 0=$ best possible score, 14=worst possible score. PEG Polyethylene glycol solution

sennosides, in its studied form, is much better tolerated but less efficacious than the standard PEG dose given alone.

Sennoside's mechanism of action has the potential to be complementary to PEG. It is an anthranoid laxative, ingested as inactive glycosides, which pass unabsorbed and unchanged through the small intestine and are hydrolyzed by bacterial glycosidases in the colon to yield active molecules. These molecules then result in increased colonic motility via increased propulsive wave activity (39). It is possible that allowing a longer time between the dosing of the sennosides and PEG would improve the quality of the colonoscopy preparation to even greater than that of PEG alone. The major advantages in tolerance for the sennosides plus PEG preparation, along with its apparently similar safety profile, suggest that it may be too early to abandon investigating this combination.

The combination of sennosides with PEG was appealing for several reasons. Few major contraindications exist to either preparation, besides bowel obstruction and those for 
TABLE 4

Postpreparation weight and hemodynamic changes

\begin{tabular}{|c|c|c|c|}
\hline & PEG & $\begin{array}{l}\text { Low-volume PEG } \\
\text { plus sennosides }\end{array}$ & $\mathbf{P}$ \\
\hline$\Delta$ Weight & $-1.89 \pm 1.89$ & $1.04 \pm 1.75$ & NS \\
\hline $\begin{array}{c}\Delta \Delta \text { Heart rate } \\
\text { (beats } / \mathrm{min} \text { ) }\end{array}$ & $-0.9 \pm 8.3$ & $-3.4 \pm 10$ & NS \\
\hline $\begin{array}{l}\Delta \Delta \text { Systolic blood } \\
\text { pressure }(\mathrm{mmHg})\end{array}$ & $-1.46 \pm 14.6$ & $-4.5 \pm 15.9$ & NS \\
\hline $\begin{array}{l}\Delta \Delta \text { Diastolic blood } \\
\text { pressure }(\mathrm{mmHg})\end{array}$ & $-5.6 \pm 10.9$ & $-7.3 \pm 9.8$ & NS \\
\hline
\end{tabular}

$\Delta$ Difference before and after preparation; $\Delta \Delta$ Difference of the difference of the postural change before and after preparation. NS Not significant; PEG Polyethylene glycol solution

colonoscopy itself. The stimulant activity of sennosides should increase bowel motility, perhaps by reducing the volume of PEG necessary for an effective colon cleansing and possibly increasing patient tolerance. Indeed, this latter benefit was borne out in the present study. Finally, a previous study (17) of the combination reported excellent results, although the applicability of these findings was unclear due to methodology limitations of the trial.

The reduced efficacy of the low-volume PEG and combined stimulant laxatives observed in the present study contrasts with previous studies $(17,30)$. Iida et al (17) described excellent results for low-volume PEG plus sennosides, but the lack of a control group combined with missing data on over $40 \%$ of patients make the conclusions based on this data difficult. DiPalma et al (30) recently described the combination of bisacodyl and low-volume PEG, with equal efficacy as fullvolume PEG. Although the current regimen of low-volume PEG plus sennosides did not have similar results, it could be due to the rigorous study design or the timing of the sennosides. Improved efficacy could possibly be achieved through giving the sennosides significantly earlier than the PEG.

In conclusion, there currently does not exist a colon cleansing preparation which is effective, well tolerated and without contraindications. While the results from the present study suggest that low-volume PEG plus sennosides is promising with respect to tolerance and safety, it must be modified to deliver improved efficacy before it can be considered ready for implementation in daily practice.

DECLARATION OF SUPPORT: This study was supported in part by an unrestricted educational grant from Purdue Pharma Canada, who also supplied the X-Prep.

ACKNOWLEDGEMENTS: The authors thank Dr Alaa Rostom for his assistance with the Ottawa scale and preparation of the manuscript.

\section{REFERENCES}

1. Harewood GC, Wiersema MJ, Melton LJ 3rd. A prospective, controlled assessment of factors influencing acceptance of screening colonoscopy. Am J Gastroenterol 2002;97:3186-94.

2. Goldman J, Reichelderfer M. Evaluation of rapid colonoscopy preparation using a new gut lavage solution. Gastrointest Endosc 1982;28:9-11.

3. Hsu CW, Imperiale TF. Meta-analysis and cost comparison of polyethylene glycol lavage versus sodium phosphate for colonoscopy preparation. Gastrointest Endosc 1998;48:276-82.

4. Aronchick CA, Lipshutz WH, Wright SH, Dufrayne F, Bergman G. A novel tableted purgative for colonoscopic preparation: Efficacy and safety comparisons with Colyte and Fleet Phospho-Soda. Gastrointest Endosc 2000;52:346-52.

5. Clarkston WK, Tsen TN, Dies DF, Schratz CL, Vaswani SK, Bjerregaard P. Oral sodium phosphate versus sulfate-free polyethylene glycol electrolyte lavage solution in outpatient preparation for colonoscopy: A prospective comparison. Gastrointest Endosc 1996;43:42-8.

6. Vanner SJ, MacDonald PH, Paterson WG, Prentice RS, Da Costa LR, Beck IT. A randomized prospective trial comparing oral sodium phosphate with standard polyethylene glycol-based lavage solution (Golytely) in the preparation of patients for colonoscopy. Am J Gastroenterol 1990;85:422-7.

7. Unal S, Dogan UB, Ozturk Z, Cindoruk M. A randomized prospective trial comparing 45 and $90-\mathrm{ml}$ oral sodium phosphate with X-Prep in the preparation of patients for colonoscopy. Acta Gastroenterol Belg 1998;61:281-4.

8. Habr-Gama A, Bringel RW, Nahas SC, et al. Bowel preparation for colonoscopy: Comparison of mannitol and sodium phosphate. Results of a prospective randomized study. Rev Hosp Clin Fac Med Sao Paulo 1999;54:187-92.

9. Barclay RL, Depew WT, Vanner SJ. Carbohydrate-electrolyte rehydration protects against intravascular volume contraction during colonic cleansing with orally administered sodium phosphate. Gastrointest Endosc 2002;56:633-8.

10. Kolts BE, Lyles WE, Achem SR, Burton L, Geller AJ, MacMath T. A comparison of the effectiveness and patient tolerance of oral sodium phosphate, castor oil, and standard electrolyte lavage for colonoscopy or sigmoidoscopy preparation. Am J Gastroenterol 1993;88:1218-23.

11. Martinek J, Hess J, Delarive J, et al. Cisapride does not improve precolonoscopy bowel preparation with either sodium phosphate or

polyethylene glycol electrolyte lavage. Gastrointest Endosc 2001;54:180-5.

12. Young CJ, Simpson RR, King DW, Lubowski DZ. Oral sodium phosphate solution is a superior colonoscopy preparation to polyethylene glycol with bisacodyl. Dis Colon Rectum 2000;43:1568-71.

13. Science backgrounder: Safety of sodium phosphates oral solution. Center for Drug Evaluation and Research, US Food and Drug Administration 2001.

14. Chan A, Depew W, Vanner S. Use of oral sodium phosphate colonic lavage solution by Canadian colonoscopists: Pitfalls and complications. Can J Gastroenterol 1997;11:334-8.

15. Hookey LC, Depew WT, Vanner S. The safety profile of oral sodium phosphate for colonic cleansing before colonoscopy in adults. Gastrointest Endosc 2002;56:895-902.

16. Love J. The appropriate use of sodium phosphates oral solutions. Can J Gastroenterol 2003;17:531. (Edit)

17. Iida Y, Miura S, Asada Y, et al. Bowel preparation for the total colonoscopy by $2000 \mathrm{ml}$ of balanced lavage solution (Golytely) and sennoside. Gastroenterol Jpn 1992;27:728-33.

18. Rostom A, Jolicoeur E. Validation of a new scale for the assessment of bowel preparation quality. Gastrointest Endosc 2004;59:482-6. (Erratum in 2004;60:326).

19. Afridi SA, Barthel JS, King PD, Pineda JJ, Marshall JB. Prospective, randomized trial comparing a new sodium phosphatebisacodyl regimen with conventional PEG-ES lavage for outpatient colonoscopy preparation. Gastrointest Endosc 1995;41:485-9.

20. Arezzo A. Prospective randomized trial comparing bowel cleaning preparations for colonoscopy. Surg Laparosc Endosc Percutan Tech 2000;10:215-7.

21. Chia YW, Cheng LC, Goh PM, et al. Role of oral sodium phosphate and its effectiveness in large bowel preparation for out-patient colonoscopy. J R Coll Surg Edinb 1995;40:374-6.

22. Frommer D. Cleansing ability and tolerance of three bowel preparations for colonoscopy. Dis Colon Rectum 1997;40:100-4

23. Golub RW, Kerner BA, Wise WE Jr, et al. Colonoscopic bowel preparations-which one? A blinded, prospective, randomized trial. Dis Colon Rectum 1995;38:594-9.

24. Henderson JM, Barnett JL, Turgeon DK, et al. Single-day, divideddose oral sodium phosphate laxative versus intestinal lavage as preparation for colonoscopy: Efficacy and patient tolerance. Gastrointest Endosc 1995;42:238-43. 
25. Lee J, McCallion K, Acheson AG, Irwin ST. A prospective randomised study comparing polyethylene glycol and sodium phosphate bowel cleansing solutions for colonoscopy. Ulster Med J 1999;68:68-72.

26. Thomson A, Naidoo P, Crotty B. Bowel preparation for colonoscopy: A randomized prospective trial comparing sodium phosphate and polyethylene glycol in a predominantly elderly population. J Gastroenterol Hepatol 1996;11:103-7.

27. Adams WJ, Meagher AP, Lubowski DZ, King DW. Bisacodyl reduces the volume of polyethylene glycol solution required for bowel preparation. Dis Colon Rectum 1994;37:229-33.

28. Borkje B, Pedersen R, Lund GM, Enehaug JS, Berstad A. Effectiveness and acceptability of three bowel cleansing regimens. Scand J Gastroenterol 1991;26:162-6.

29. Clarkston WK, Smith OJ. The use of golytely and dulcolax in combination in outpatient colonoscopy. J Clin Gastroenterol 1993;17:146-8.

30. DiPalma JA, Wolff BG, Meagher A, Cleveland M. Comparison of reduced volume versus four liters sulfate-free electrolyte lavage solutions for colonoscopy colon cleansing. Am J Gastroenterol 2003;98:2187-91.

31. El Sayed AM, Kanafani ZA, Mourad FH, et al. A randomized singleblind trial of whole versus split-dose polyethylene glycol-electrolyte solution for colonoscopy preparation. Gastrointest Endosc 2003;58:36-40.

32. Hangartner PJ, Munch R, Meier J, Ammann R, Buhler H. Comparison of three colon cleansing methods: Evaluation of a randomized clinical trial with 300 ambulatory patients. Endoscopy 1989;21:272-5.
33. Lazarczyk DA, Stein AD, Courval JM, Desai D. Controlled study of cisapride-assisted lavage preparatory to colonoscopy. Gastrointest Endosc 1998;48:44-8.

34. Mukai M, Tajima T, Suzuki R, et al. Reducing the volume of polyethylene glycol electrolyte lavage solution to less than 2 liters for bowel preparation. Tokai J Exp Clin Med 2000;25:27-32.

35. Poon CM, Lee DW, Mak SK, et al. Two liters of polyethylene glycolelectrolyte lavage solution versus sodium phosphate as bowel cleansing regimen for colonoscopy: A prospective randomized controlled trial. Endoscopy 2002;34:560-3.

36. Sharma VK, Steinberg EN, Vasudeva R, Howden CW. Randomized, controlled study of pretreatment with magnesium citrate on the quality of colonoscopy preparation with polyethylene glycol electrolyte lavage solution. Gastrointest Endosc 1997;46:541-3.

37. Sharma VK, Chockalingham SK, Ugheoke EA, et al. Prospective, randomized, controlled comparison of the use of polyethylene "glycol electrolyte lavage solution in four-liter versus two-liter volumes and pretreatment with either magnesium citrate or bisacodyl for colonoscopy preparation. Gastrointest Endosc 1998;47:167-71

38. Ziegenhagen DJ, Zehnter E, Tacke W, Kruis W. Addition of senna improves colonoscopy preparation with lavage: A prospective randomized trial. Gastrointest Endosc 1991;37:547-9.

39. Lennard-Jones JE. Constipation. In: Feldman M, Friedman LS, Sleisenger MH, eds. Sleisenger \& Fordtran's Gastrointestinal and Liver Disease, 7th edn. Philadelphia: Elsevier Science, 2002:181-211. 


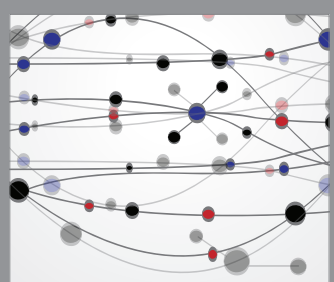

The Scientific World Journal
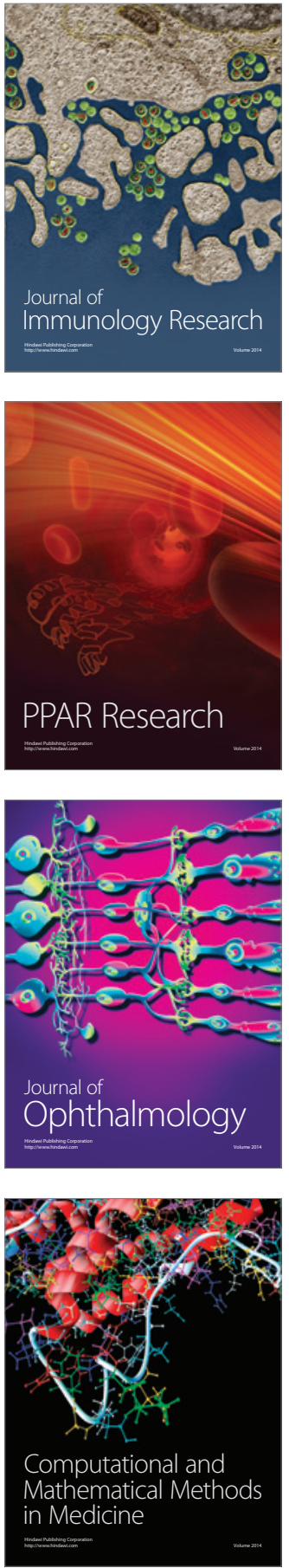

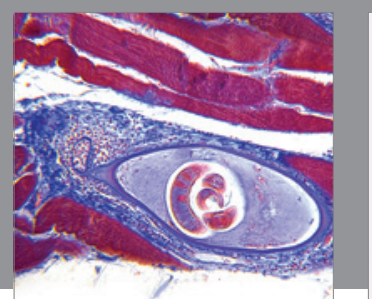

Gastroenterology Research and Practice

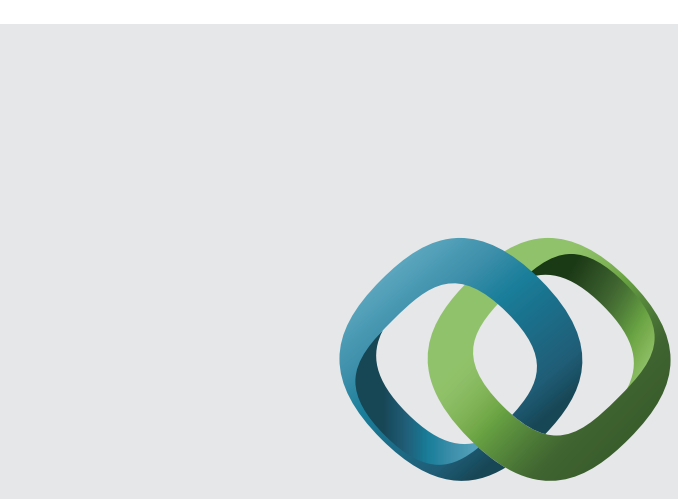

\section{Hindawi}

Submit your manuscripts at

http://www.hindawi.com
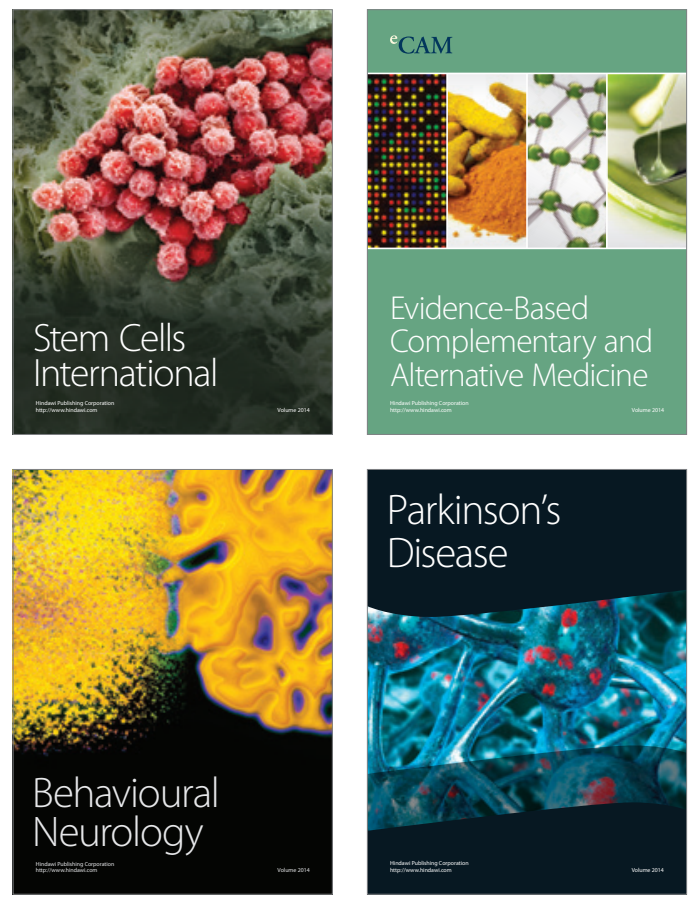
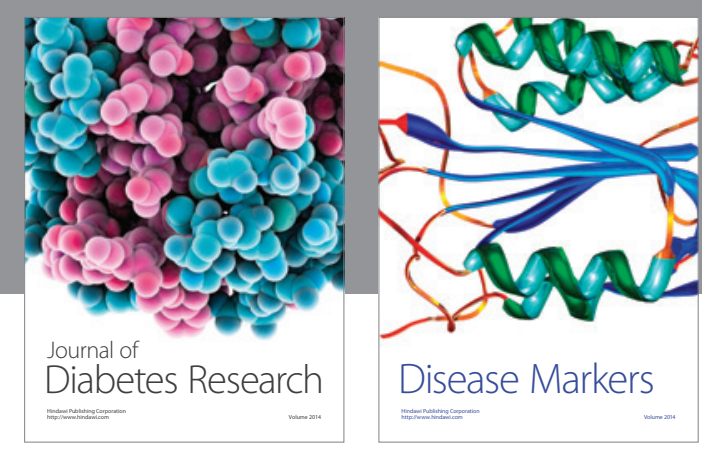

Disease Markers
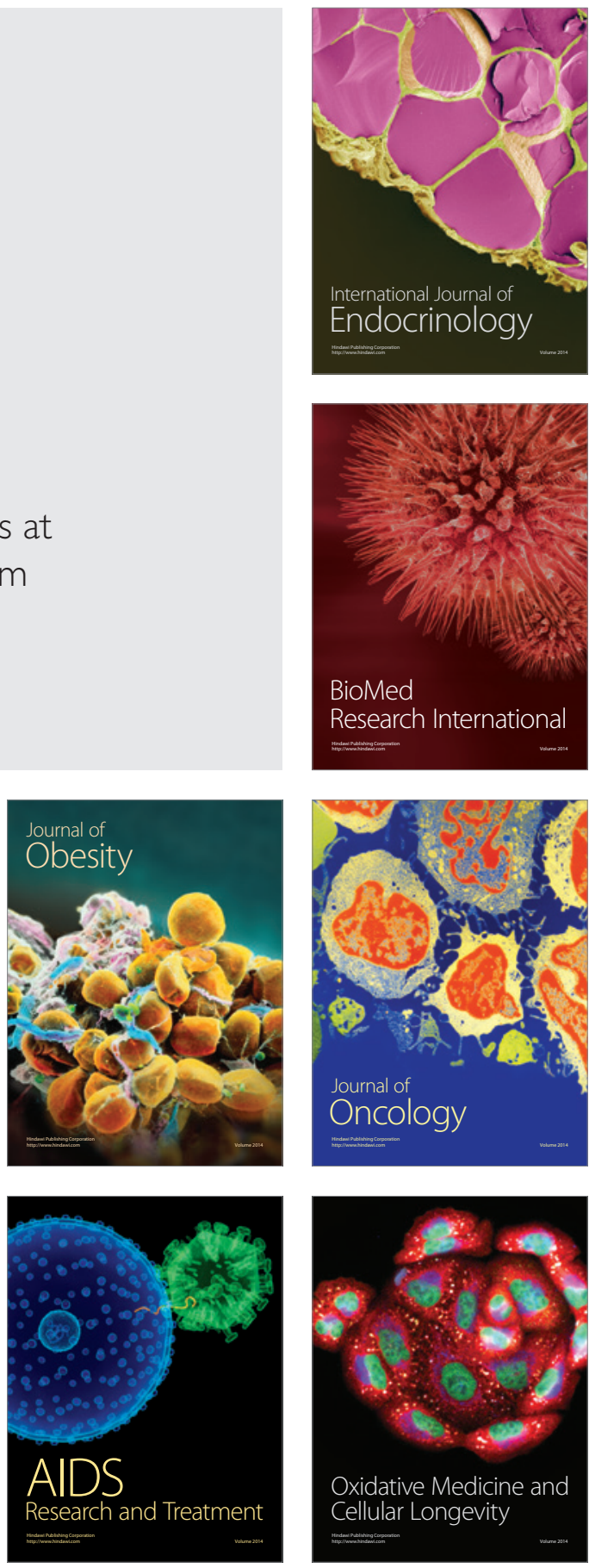